\title{
Pengering Ekonomis Untuk Optimalisasi Kapasitas Produksi Rengginan
}

\author{
Roby Syaiful Ubed*1, Taufik Raharjo ${ }^{2}$, Ambang Aries Yudanto ${ }^{3}$ \\ 1,2,3Politeknik Keuangan Negara STAN; Jl Bintaro Utama 3A No.V, Bintaro, Ciputat Timur, Tangerang \\ Selatan, Banten, 021-7361654 \\ Program Studi D3 Manajemen Aset, Jurusan Manajemen Keuangan, Politeknik Keuangan Negara STAN \\ *e-mail: robyubed@pknstan.ac.id
}

\begin{abstract}
The purpose of this service is to make a small scale dryer for Micro, Small and Medium Enterprises (MSMEs). This tool will help optimize the production process, to increase partner income. This tool is made with materials that are economical and easily obtained by partners. The method of carrying out community service activities is divided into three stages, namely the identification of problems and action plans, preparation, and implementation of activities. The results of the implementation of community service activities can be concluded that this activity has been able to have a positive impact on the process of inorganic production. This tool needs to be improved by adding a thermostat to measure the appropriate temperature in product drying and can set the time automatically. The accuracy of the effectiveness of this tool needs to be done with laboratory tests to test the level of water content, sensory tests, and texture tests. These tests are conducted so that production activities no longer use the feelings of partners in measuring the desired results.
\end{abstract}

Keywords: Service, Dryer, Micro, Small and Medium Enterprises

\section{Abstrak}

Tujuan pengabdian ini adalah membuat alat pengering rengginan skala Usaha Mikro Kecil dan Menengah (UMKM). Alat ini akan membantu optimalisasi proses produksi, sehingga mampu meningkatkan pendapatan mitra. Alat ini dibuat dengan bahan yang ekonomis dan mudah didapatkan oleh mitra. Metode pelaksanaan kegiatan pengabdian kepada masyarakat ini dibagi menjadi tiga tahap, yaitu identifikasi masalah dan rencana aksi, persiapan, dan pelaksanaan kegiatan. Hasil pelaksanaan kegiatan pengabdian kepada masyarakat ini dapat disimpulkan bahwa kegiatan ini telah mampu berdampak positif dalam proses produksi rengginan. Alat ini perlu disempurnakan dengan menambah termostat untuk mengukur suhu yang sesuai dalam pengeringan produk serta dapat mengatur waktu secara otomatis. Akurasi efektivitas alat ini perlu dilakukan dengan uji laboratorium untuk menguji tingkat kadar air, uji sensori, dan uji tekstur. Uji-uji ini dilakukan agar kegiatan produksi sudah tidak lagi menggunakan perasaan mitra dalam mengukur hasil yang diinginkan.

Kata kunci: Pengabdian, Alat Pengering, Usaha Mikro Kecil dan Menengah

\section{PENDAHULUAN}

Desa cibogo, salah satu desa yang terletak di wilayah Kabupaten Tangerang, merupakan desa yang masuk dalam kategori desa maju. Letak geografis yang strategis, dan didukung fasilitas Stasiun Kereta Rel Listrik (KRL) Cisauk, mendukung desa ini mengalami percepatan pembangunan yang dilakukan oleh pihak swasta dengan membuat beberapa kawasan perumahan. Pembangunan Desa Cibogo ini ternyata belum berdampak langsung terhadap peningkatan kesejahteraan warga sekitar. Desa dengan jumlah penduduk sebesar 15.502 jiwa dengan jumlah usia produktif sejumlah 10.747 jiwa. Namun tercacat pula jumlah penduduk yang kurang produktif mencapai 3.967 jiwa yang berperan menyumbang jumlah penduduk miskin sebesar 536 keluarga yang didominasi oleh penduduk asli desa ini. Kondisi ini membuat kesenjangan sosial antara penduduk asli desa ini dengan penduduk pendatang.

Berdasarkan wawancara dengan Kepala Desa dan Sekretaris Desa, tingginya angka penduduk yang tidak bekerja diakibatkan perubahan lahan pekerjaan. Dahulu desa ini terkenal dengan pertambangan pasir dan batu, sehingga sebagian besar penduduknya mengandalkan mata pencaharian dari pertambangan tersebut sebagai buruh bongkar muat. Seiring waktu 
berjalan, pertambangan pasir dan batu sudah tinggal sedikit karena sumber daya alam yang tidak dapat terbarukan, alhasil banyak buruh bongkar muat pertambangan tersebut kesulitan mendapatkan pekerjaannya. Sebenarnya pembangunan desa dan kawasan sekitarnya mampu menyediakan lapangan pekerjaan baru, namun hal ini belum bisa ditangkap oleh penduduk yang tidak bekerja tadi dengan alasan usia dan kempetensi yang tidak sesuai lagi tuntutan penyedia lapangan pekerjaan. Selain itu, ada pula masalah lain berupa banyaknya warga yang terikat dengan rentenir karena alasan pemenuhan kebutuhan.

Kabar baiknya, di desa tersebut terdapat beberapa usaha masyarakat secara mandiri. Usaha-usaha tersebut antara lain usaha pembuatan makanan kecil seperti rengginang, opak, kripik sentul, telur gabus, dodol, dan tape singkong, kripik pisang, dan lain-lain. Sesuai dengan kapasitasnya, usaha-usaha masyarakat ini masuk dalam kategori Usaha Mikro Kecil dan Menengah (UMKM). Tambunan [8] mendefinisikan UMKM sebagai unit usaha produktif yang berdiri sendiri, yang dilakukan oleh orang perorangan atau Badan Usaha disemua sektor ekonomi. Dari kapasitas usaha yang dilakukan warga desa Cibogo, maka kapasitas usahanya termasuk dalam usaha mikro, dimana usaha mereka merupakan usaha milik orang perorangan dan/atau badan usaha perorangan yang total aset usahanya tidak lebih dari 50 juta rupiah, dan omsetnya tidak sampai 300 juta rupiah [9].

\subsection{Permasalahan}

Berdasarkan informasi yang didapatkan, Desa cibogo ternyata mempunyai potensi usaha yang cukup potensial. Namun potensi-potensi usaha ini kurang dapat berkembang dan bersaing dengan produk-produk sejenis. Menurut analisis pengabdi, potensi usaha warga ini seharusnya dapat menjadi potensi pendapatan masyarakat yang mampu diandalkan jika dikelola secara baik. Untuk itu, kami mencoba mengembangkan beberapa produk usaha warga desa Cibogo ini menjadi lebih baik dan dapat dijadikan Produk Unggulan Kawasan Perdesaan (Prukades) yang mampu menjadi alternatif tulang punggung perekonomian masyarakat desa Cibogo. Menurut Maryanti [3], Prukades merupakan semangat UMKM melalui pendekatan One Village One Product (OVOP) atau "satu desa satu produk" yang merupakan upaya untuk meningkatkan daya saing produk unggulan desa sehingga mampu bersaing dengan produk di pasaran, memiliki ciri khas desa, dan memanfaatkan sumber daya lokal.

Untuk mendapatkan hasil yang efektif maka dalam pengabdian ini kami akan lebih berfokus untuk mendampingi mitra yang barada dalam wilayah RT 10/ RW 02, lebih fokus lagi kepada salah satu pengrajin rengginan, yaitu Ibu Dede. Adapun masalah dalam menjalankan usaha adalah proses produksi yang masih manual dan mengandalkan cuaca sebagai metode pengeringan produk. Kegiatan pengabdian ini merupakan keberlanjutan dari kegiatan pengabdian yang dilakukan oleh Yudanto [3]. Tujuan kegiatan pengabdian masyarakat ini adalah membantu membuatkan alat pengering rengginan yang mampu mengoptimalkan kapasitas produksi produk tersebut.

\section{METODE}

Kegiatan pengabdian masyarakat ini dibagi menjadi tiga tahap, yaitu:

1.Identifikasi masalah dan rencana aksi

Tahap ini mencoba mencari masalah yang ada dalam usaha mitra dan kemudian membuat rencana aksi untuk memberikan solusi dari permasalahan yang ada. Hal ini dilakukan agar kegiatan pengabdian ini tepat manfaat.

2.Persiapan

Setelah mendapatkan rencana aksi maka dilakukan persiapan kegiatan pengabdian masyarakat.

3.Pelaksanaan kegiatan

Kegiatan pengabdian ini dilaksanakan untuk menindakanjuti rencana kegiatan dan mencoba menyelesaikan masalah yang telah diidentifikasi. 


\section{HASIL DAN PEMBAHASAN}

Hasil pengabdian kepada masyarakat ini mendapatkan beberapa hasil yang diharapkan mempunyai efek positif bagi mitra.

\subsection{Identifikasi Masalah dan rencana solusi}

Pada tahap identifikasi masalah dilakukan pengumpulan data yang akan diperlukan yaitu melalui metode berupa pengumpulan data sekunder dari mitra mengenai proses dan kapasitas produksi. Data yang didapatkan bahwa saat ini kapasitas produksi mampu mencapai 250 buah rengginan siap makan setiap harinya. Kapasitas ini disesuaikan dengan jumlah pesanan yang dijual di pasar Kebayoran. Salah satu kendala yang muncul adalah kondisi cuaca yang tidak menentu, jika cuaca tidak panas atau bahkan hujan, akan sangat menekan besaran produksi rengginan. Untuk mengatasi masalah ketergantungan pada cuaca, Heriansyah [1] dan Kuncoro [2] telah mencoba memberikan introduksi mesin pengering dalam proses produksi makanan tradiosnal yang sangat membantu mitra dalam produksi produknya. Dalam program pengabdian kepada masyarakat yang dilakukan oleh Sudarno [7], mesin pengering rengginan sangat bermanfaat untuk mempercepat proses pengeringan, sehingga mengurangi risiko jamur pada rengginan dan tidak laku dijual yang berakibat kerugian bagi mitra

\subsection{Persiapan}

Salah satu output dari kegiatan ini adalah alat pengering produk yang nantinya akan dibuat menggunakan bahan dan material yang disesuaikan dengan ketersediaan anggaran kegiatan. Berdasarkan diskusi dengan para pelaku UMKM, salah satu kendala mereka adalah proses pengeringan produk yang sangat tergantung dengan cuaca. Pengeringan adalah proses penurunan kadar air bahan untuk memperlama umur bahan. Kadar air bahan harus diturunkan untuk mengurangi aktifitas air (water activity) sehingga bahan makanan menjadi lebih lama umur pemakaiannya. Dengan dibuatnya alat pengering, diharapkan para pelaku UMKM dapat terus berproduksi meskipun terjadi perubahan cuaca.

Dalam tahap persiapan, kami terlebih dahulu membuat desain alat pengering (Gambar 1) yang nantinya akan mengoptimalkan proses produksi. Ide awal sesain alat ini mengadopsi dari desain alat yang telah diciptakan oleh Sirait [2] dan sudah diterapkan oleh Saptariana [1] serta Mumpuni [4]. Namun karena dirasa desain dan bahan yang digunakan oleh Sirait [2] serta Mumpuni [4] dinilai terlalu mahal dan kurang cocok bagi usahawan bermodal mikro, karena menggunakan bahan baku yang terbuat dari metal dan bahan bakar gas. Jadi alat yang digunakan sistemnya seperti oven dengan pemanas api. Hal ini dirasa tidak sesuai dengan kebutuhan dan keinginan mitra dengan modal kecil, maka desain konsep alat pengering kami modifikasi secara menyeluruh.

Bahan metal kami ganti dengan bahan kayu karena bahan ini mudah didapat dan harganya cukup terkangkau bagi mitra. Bahan lain yang diperlukan adalah blower sebagai pengganti sumber angin dan lampu bohlam sebagai sumber pemanas pengganti kompor gas. Dengan mengoptimalkan pemanasan dari bohlam dan sirkulasi udara menggunakan blower, diharapkan bahan makanan dapat kering dalam waktu yang lebih singkat.

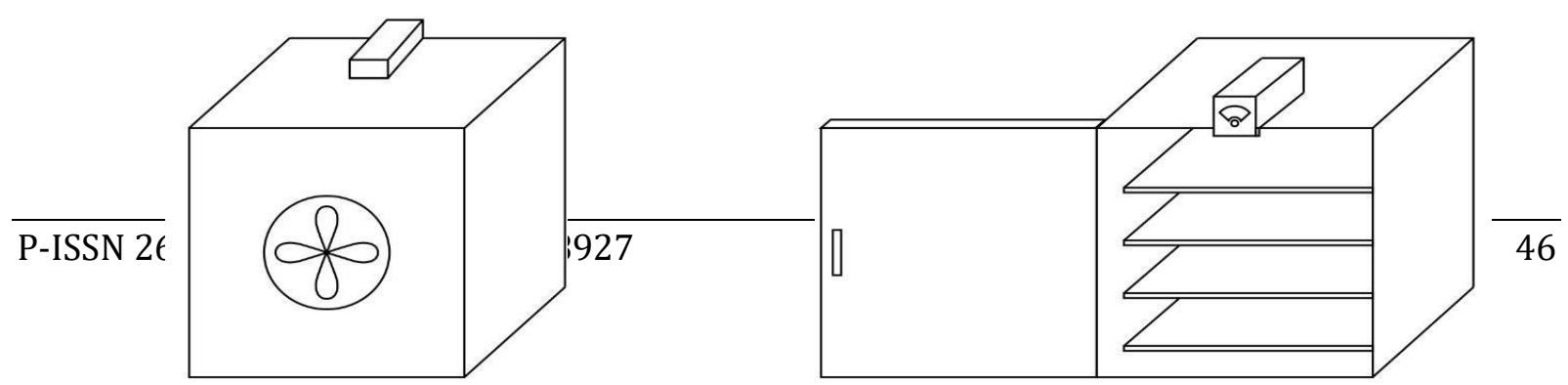


Gambar 1. Desain alat pengering renginan

\subsection{Pelaksanaan}

Dalam tahap pelaksanaan ini dilakukan dua kegiatan, pertama pembuatan alat pengering dan kedua adalah uji coba alat ini untuk melihat efektifitas hasil alat ini. Pembuatan alat ini dilakukan oleh warga setempat yang bekerjasasama dengan pengabdi.

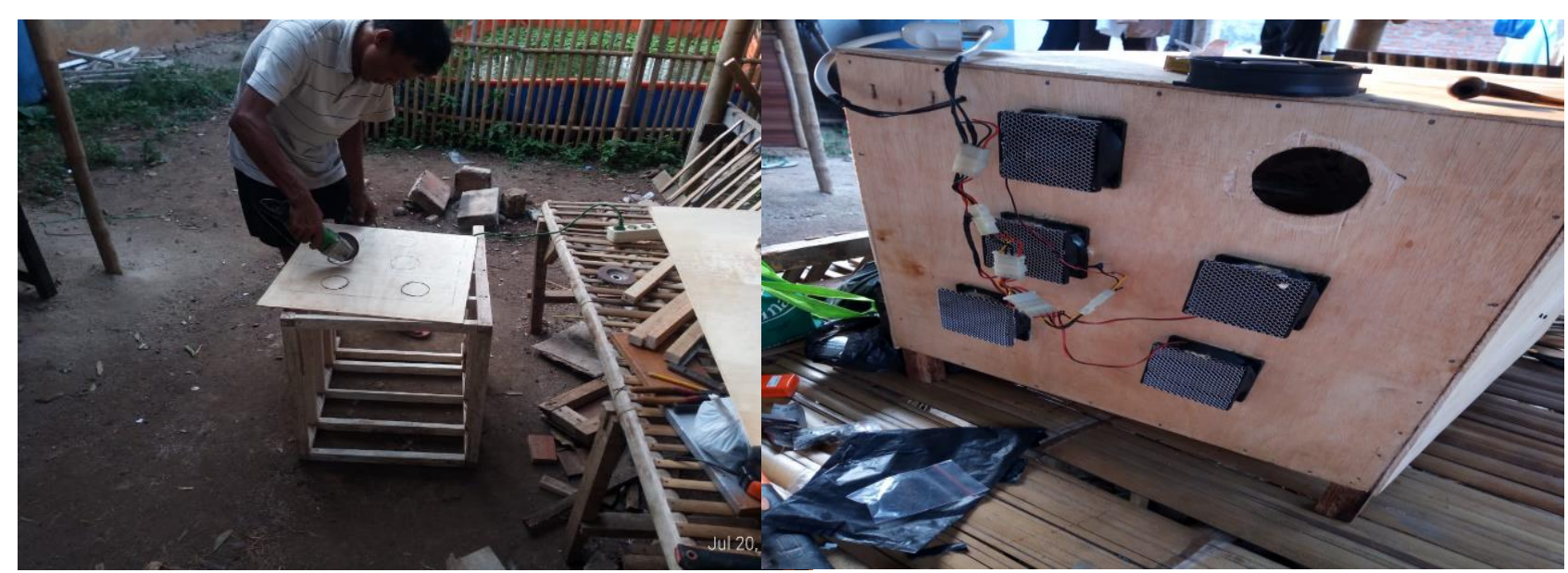

Gambar 2. Proses pembuatan alat pengering

Bahan baku alat ini dipilih dari material kayu dan tripilek yang dirasa lebih ekonomis dari sisi biaya serta mudah didapatkan di toko bangunan sekitar tempat tinggal mitra. Selain itu dengan bahan tersebut, pembuatannya sederhana sehingga dapat dilakukan oleh masyarakat secara mandiri, tanpa harus dikerjakan oleh workshop khusus. Blower yang digunakan dalam kegiatan ini adalah blower bekas dari perangkat computer bekas. Untuk menggerakkan blower sendiri awalnya menggunakan adaptor charger handpohone bekas. Sebagai pemanas, alat ini menggunakan enam lampu pijar dengan daya 10 watt setiap lampunya yang dipasang di dinding kanan maupun kirin alat pengering ini.

Setelah alat tersebut jadi, selanjutnya dilakukan proses ujicoba. Uji coba dilakukan oleh pengrajin rengginan dengan bahan rengginan mentah yang baru dikukus. Uji coba pertama dilakukan selama empat jam. Ternyata hasilnya tidak memuaskan, alat ini tidak bekerja secara baik. Setelah dievaluasi, ternyata hembusan angin yang didapatkan ternyata tidak maksimal. Selanjutnya alat dimodifikasi dengan mengganti charge handphone sebagai sumber listrik blower dengan dua charger laptop yang akan memutarkan enam blower sekaligus. Selain mengganti charger, modifikasi dilakukan dengan mengganti dua lambu pijar daya 10 watt dengan dua daya 60 watt, sehingga mampu mendapatkan panas yang lebih baik.

Setelah dimodifikasi, uji coba ke-dua dilakukan. Hasil yang didapatkan dari uji coba kedua juga tidak berhasil. Setelah dievaluasi kembali, hal ini dikarenakan ruangan pengering ini malah menjadi dingin karena hempusan angin yang terlalu kencang. Maka tanpa modifikasi, uji coba ke-tiga dilakukan dengan hanya menghidupkan lampu pijar, tanpa mengaktifkan blower. Percobaan ketiga rupanya lebih berhasil, namun hasil keringnya tidak memuakan. 
Karena target hasil yang diharapkan haruslah seperti hasil pengeringan menggunakan matahari sehingga dapat segera digoreng dan mengasilkan sensi renyah.

Setelah uji coba ketiga belum memuaskan, maka modifikasi selanjutnya adalah dengan mengganti seluruh lampu pijar (enam) dengan daya 60 watt setiap lampunya. Hal ini pasti akan mengahasilkan panas ruang pengering meningkat, namun akan berdampak pada konsumsi listrik. Uji coba ke-empat dilakukan dengan meghidupkan enam lampu pijar tanpa menghidupkan blower. Evaluasi uji coba ke-empat ini rupanya membuahkan hasil yang optimal selama tiga jam. Dengan kemampuan perasaan mitra dalam memperkirakan kadar air pengeringan, mitra merasa rengginang sudah kering pada tiga jam. Setelah dirasa kering, maka langkah selanjutnya adalah menggoreng hasil rengginang kering tadi, dan ternyata hasilnya sesuai dengan harapan atau sama persis dengan hasil pengeringan dengan sistem jemur matahari. Rasa tetap terjaga, sensasi renyah juga masih didapatkan. Sehingga kami merasa tujuan kegiatan ini sudah tercapai dan alat ini benar-benar berfungsi sebagai mana mestinya untuk meningkatkan produksi dalam kondisi cuaca bagaimanapun, asal masih ada listrik.

\section{KESIMPULAN}

Setelah pelaksanaan kegiatan pengabdian kepada masyarakat ini dapat disimpulkan bahwa kegiatan ini telah mampu berdampak positif dalam proses produksi rengginan. Untuk menyempurnakan, alat ini perlu dimodifikasi lagi, yaitu dengan menambah termostat untuk mengukur suhu yang sesuai untuk pengeringan produk dan dapat mengatur waktu secara otomatis. Penyempurnaan alat ini dilakukan agar dapat digunakan sewaktu-waktu sesuai keinginan tanpa harus dikontrol waktunya secara manual, karena dengan termostat, alat pemanas ini akan mati secara otomatis jika penggunaan sudah selesai, sehingga mampu mengurangi risiko kebakaran.

Selain perbaikan alat, perlu juga uji laboratorium untuk menguji tingkat kadar air, uji sensori, dan uji tekstur. Uji kadar air dilakukan untuk mengukur kesesuaian kekeringan produk, Uji sensori digunakan untuk mengukur standar rasa yang diinginkan, dan uji tektur dilakukan untuk mengukur tingkat kekerasan hasil pengeringan. Uji-uji ini dilakukan agar kegiatan produksi sudah tidak lagi menggunakan perasaan mitra untuk mengukur kekeringan rengginan.

\section{SARAN}

Kegaitan pengabdian kepada masyarakat ini masih mempunyai banyak kekurangan. Sehingga saran-saran untuk untuk pengabdian lebih lanjut untuk menutup kekurangan pengabdian kepada masyarakat ini adalah dengan mengambangkan kegiatan pendampingan kepada mitra. Metode yang digunakan dapat disesuaikan dengan kodisi mitra maupun kondisi pengabdi.

\section{UCAPAN TERIMA KASIH}

Ucapakan terimakasih kami sampaikan kepada mitra yang telah bersedia berkerjasama dengan Politeknik Keuangan Negara STAN (PKN STAN) dalam agenda pengabdian kepada masyarakat. Semoga pelaksanaan kegiatan pengabdian ini dapat tetap terlaksana secara berkelanjutan dan membawa manfaat bagi masyarakat, khususnya mitra dan masyarakat sekitar yang nantinya dapat mengunakan alat pengering ini.

\section{DAFTAR PUSTAKA}

Heriansyah, H., Fachri, H., Selviana, S., \& Suwarni, L, 2019. PKM Inovasi Teknologi Pengolahan Taro Tela Dan Rengginang Pada Kelompok Transmigran. JPM17: Jurnal Pengabdian Masyarakat, 4(1)

Kuncoro, E. A, 2019. Introduksi Alat Pengering Untuk Meningkatkan Produksi Dan Kualitas 
Rengginang Di Desa Sukamulya Kecamatan Indralaya Utara Kabupaten Ogan Ilir. Jurnal Pengabdian Sriwijaya, 7(1), 695-699

Maryanti, S., Sudiar, N., \& Suci, A, 2019. Konsep OVOP Untuk Mengidentifikasi Produk Unggulan Daerah (Studi Kasus Wajik Tapai Melayu). Dinamisia: Jurnal Pengabdian Kepada Masyarakat, Vol 3, Special Issue, 188-191

Mumpuni, I. D., Dewa, W. D. A., \& Widarti, D. W, 2017. IbM Industri Rumah Tangga Rengginang Ketan Di Desa Lingkup Kecamatan Sumber Pucung Kabupaten Malang. Jurnal Dedikasi, 14, 21-26

Saptariana, Putri, M. F, \& Agustina, T, 2014. Peningkatan Kualitas Produksi Rengginang Ketan Menggunakan Teknologi Pengering Buatan. Rekayasa, No 1, Vol 12, 10-15

Sirait, J, 2012. Pembuatan Alat Pengering Kerupuk Rengginang Dengan Kapasitas 7 Kg di Samarinda. Jurnal Riset Reknologi Indutri, No 11, Vol 6, 29-38

Sudarno, S., \& Huriyah, H, 2018. PKM Kelompok Industri Rumah Tangga Rengginang Desa Walen Simo Boyolali. In Prosiding Seminar Nasional Unimus (Vol. 1).

Tambunan, Tulus, 2012. "Usaha Mikro Kecil dan Menengah di Indonesia : isu-isu penting", Jakarta : LP3ES.

Undang-Undang Republik Indonesia Nomor 20 Tahun 2008 tentang Usaha Mikro, Kecil, dan Menengah

Yudanto, A. A., Raharjo, T., \& Ubed, R. S, 2018. Pendampingan Pengembangan Produk Unggulan Kawasan Perdesaan Pada Usaha Berbasis Komunitas Desa Cibogo. Dinamisia: Jurnal Pengabdian Kepada Masyarakat, No 2, Vol 2, 161-166 